\title{
Personality traits, migration intentions, and cultural distance
}

Citation for published version (APA):

Fouarge, D., Özer, M. N., \& Seegers, P. (2018). Personality traits, migration intentions, and cultural distance. Maastricht University, Graduate School of Business and Economics. GSBE Research Memoranda No. 028 https://doi.org/10.26481/umagsb.2018028

Document status and date:

Published: 18/12/2018

DOI:

10.26481/umagsb.2018028

Document Version:

Publisher's PDF, also known as Version of record

\section{Please check the document version of this publication:}

- A submitted manuscript is the version of the article upon submission and before peer-review. There can be important differences between the submitted version and the official published version of record.

People interested in the research are advised to contact the author for the final version of the publication, or visit the DOI to the publisher's website.

- The final author version and the galley proof are versions of the publication after peer review.

- The final published version features the final layout of the paper including the volume, issue and page numbers.

Link to publication

\footnotetext{
General rights rights.

- You may freely distribute the URL identifying the publication in the public portal. please follow below link for the End User Agreement:

www.umlib.nl/taverne-license

Take down policy

If you believe that this document breaches copyright please contact us at:

repository@maastrichtuniversity.nl

providing details and we will investigate your claim.
}

Copyright and moral rights for the publications made accessible in the public portal are retained by the authors and/or other copyright owners and it is a condition of accessing publications that users recognise and abide by the legal requirements associated with these

- Users may download and print one copy of any publication from the public portal for the purpose of private study or research.

- You may not further distribute the material or use it for any profit-making activity or commercial gain

If the publication is distributed under the terms of Article $25 \mathrm{fa}$ of the Dutch Copyright Act, indicated by the "Taverne" license above, 


\section{Maastricht University}

Didier Fouarge,

Merve Nezihe Özer,

Philipp Seegers

Personality traits, migration intentions, and cultural distance

RM/18/028

\section{GSBE}

Maastricht University School of Business and Economics

Graduate School of Business and Economics

P.O Box 616

NL-6200 MD Maastricht

The Netherlands 


\title{
Personality traits, migration intentions, and cultural distance
}

\author{
Didier Fouarge ${ }^{\text {a,b,c,d }}$, Merve Nezihe Özer ${ }^{\text {a,b, }}$, Philipp Seegers ${ }^{\text {b,e }}$
}

\begin{abstract}
Personality traits are influential in individual decision-making but have been overlooked in economic models of migration. This paper investigates the relation between Big Five personality traits and individuals' migration intentions among alternative destinations that vary in their culture distance. We hypothesize that Big Five personality traits may alter individuals' migration decision and destination choice through their influence on perceived psychic costs and benefits of migration. We test our hypotheses using the Fachkraft survey conducted among university students in Germany. We find that extraversion and openness are positively associated with migration intentions, while agreeableness, conscientiousness, and emotional stability negatively relate to migration intentions. We show that openness positively and extraversion negatively relate to the willingness to move to culturally distant countries even when we control for geographic distance and economic differences between countries. Using language as a cultural distance indicator provides evidence that extravert individuals are less likely to prefer linguistically distant countries while agreeable individuals are more inclined to consider such countries as alternative destinations.
\end{abstract}

Keywords: migration intention, destination choice, cultural distance, Big Five personality traits

JEL Classification: D91, J61, Z1

\footnotetext{
${ }^{\text {a }}$ Research Centre for Education and the Labour Market (ROA), Maastricht University, Maastricht, The Netherlands

${ }^{\mathrm{b}}$ Department of Economics, Maastricht University, Maastricht, The Netherlands

${ }^{c}$ Network for Studies on Pensions, Aging and Retirement (NETSPAR), Tilburg University, Tilburg, The Netherlands

${ }^{\mathrm{d}}$ Institute of Labor Economics (IZA), Bonn, Germany

${ }^{\mathrm{e}}$ Candidate Select GmbH (CASE), Cologne, Germany

* Corresponding author at: Research Centre for Education and the Labour Market (ROA), Maastricht University, P.O. Box 616 6200MD Maastricht, The Netherlands. T: +31 433883598, F: +31 433884914, E-mail: m.ozer@ maastrichtuniversity.nl

We gratefully acknowledge comments from Frank Cörvers, Davey Poulissen, and seminar participants at the XIX Applied Economics Meeting 2016. The views expressed herein are those of the authors and do not necessarily reflect the views of institutions that authors are affiliated.
} 


\section{INTRODUCTION}

Labor migration is theorized in neoclassical economic literature as an investment decision driven by human capital characteristics of individuals and expected wage gains (Massey et al., 1993). Despite their significant impact on individuals' decision to migrate, these factors are not sufficient to explain why some individuals migrate while others do not even if they share the same prospects for economic gain and socio-demographic characteristics. This is because the decision to migrate is a complex process that is also influenced by noneconomic factors such as cultural differences (Belot and Ederveen, 2012) and individuals' perception of potential costs and benefits of migration. These perceptions are shaped by preferences (Bauernschuster et al., 2014; Czaika, 2012; Groenewold et al., 2012) and psychological dispositions (Fawcett, 1985). Personality traits are influential in a large array of economic decisions (Becker et al., 2012) but have been overlooked in economic models of migration. This paper contributes to this thin literature by investigating the relation between personality traits and individuals' intentions to migrate to culturally different alternative destinations.

This paper hypothesizes that individuals' personality traits affect the way they weigh the psychic costs and benefits of migrating to alternative locations. Alternative locations differ in their economic and noneconomic characteristics. The attractiveness of rich and well-developed regions is well documented in literature (Bertoli et al., 2013; Mayda, 2010; Pedersen et al., 2008). Culture, is one of the non-economic dimensions influencing the attractiveness of alternative destinations for potential migrants (Bauernschuster et al., 2014; Belot and Ederveen, 2012; Wang et al., 2016). However, little is known about how cultural differences are subjectively evaluated by individuals with different personalities. For example, one could expect that individuals scoring high on openness to new experiences (one of the Big Five personality traits) have a more positive perception of the net benefits of migrating to culturally more remote regions. ${ }^{1}$ Answering this question is important to gain insights about how immigrants are self-selected and sorted into alternative destinations, and the implications of this sorting for the integration in culturally different environments.

To the best of our knowledge, Ayhan et al. (2017) and Bütikofer and Peri (2017) are the only papers addressing the role of personality in migration decisions with an economic outlook. Ayhan et al. (2017) found that openness is positively associated with higher propensity of migration from rural to urban areas while conscientiousness is negatively related to rural-urban migration in Ukraine. They also find a negative

\footnotetext{
${ }^{1}$ Definitions of personality traits used in literature vary. We focus on the Big Five taxonomy in which personality is broken down into five main dimensions: extraversion, agreeableness, conscientiousness, emotional stability, and openness to new experiences (Goldberg, 1992). Our data includes measurements of personality traits according to this taxonomy.
} 
relation between extraversion and propensity to migrate from rural areas to cities. Bütikofer and Peri (2017) analyzed the migration patterns of Norwegian male population born in 1932-1933 enlisted for military service using two non-cognitive skills called adaptability and sociability and found that adaptability skills have a strong impact on migration. Although the latter of these two studies included an analysis for emigration from Norway, both focused on internal migration and treat location choice as a preference over different administrative units within a country.

Migration psychology literature provides a more extensive treatment on the relation between personality traits and migration. There is a consensus in this literature on the positive association between migration and openness and extraversion (Camperio Ciani et al., 2007; Canache et al., 2013; Jokela, 2009; Jokela et al., 2008; Paulauskaite et al., 2010; Silventoinen et al., 2008). However, evidence for other traits is ambiguous. Paulauskaite et al. (2010) found a negative relation between conscientiousness and the intention to emigrate, and Jokela (2009) did not find such a significant association. Similarly, Paulauskaite et al. (2010) did not find a relationship between the intention to migrate and agreeableness while Jokela (2009) showed that less agreeable individuals are more likely to migrate. Moreover, Huang et al. (2005) found that agreeableness is positively associated with adaptation to local community once migration occurred. For neuroticism, Silventoinen et al. (2008) and Jokela et al. (2008) found a positive relationship with the intention to migrate while Jokela (2009) did not find a significant association.

Although migration decisions involve the choice of where to move, fewer studies addressed the potential role of personality traits on location choices. Jokela et al. (2008) found that highly sociable (i.e., extravert) individuals are more likely to migrate longer distances and to prefer urban areas while highly emotional (i.e., neurotic) individuals tend to migrate shorter distances. Murray et al. (2005) found that individuals living in highly accessible locations in Australia (where opportunities for social interaction and services are more abundant) have higher levels of openness and extraversion. In these papers, either preferences over different administrative units to live or geographic distance is used as proxies of location choice. However, these proxies do not fully capture the potential costs associated with migrating to culturally distant locations. To the best of our knowledge, we are the first to investigate the association between personality traits and the perception of alternative destination countries based on cultural distance.

We test the hypothesis that personality traits are related to the migration decision using the Fachkraft data gathered among students at German universities in March 2015. Students were asked whether they want to work abroad after they graduate and, if yes, in which country. ${ }^{2}$ The survey also includes a fifty item IPIP Big Five personality test by Goldberg (1992). We estimate two models to test the relation between the

\footnotetext{
${ }^{2}$ This means we define migration as voluntary labor migration in this study.
} 
various facets of personality and students' migration intentions and their preferences over alternative destinations that we characterize based on cultural distance. We construct a measure of cultural distance using Hofstede national culture dimensions indicating cultural difference between Germany and the countries students prefer to work. Our results show that being more extravert and open to new experiences is associated with stronger intentions to migrate while being more agreeable, conscientious, and emotionally stable is correlated with lower migration intentions. We show that openness positively and extraversion negatively relate to the willingness to move to countries culturally more remote, even when we control for geographic distance and economic differences between countries. Our robustness checks using language distance show that extraverts are significantly less likely to prefer countries where German and English are not official languages, and that more agreeable students are more likely to consider these countries as alternative destinations.

The paper is structured as follows. Section 2 provides a conceptual framework for our hypotheses. Our data and estimation strategy are introduced in Section 3 and Section 4, respectively. Section 5 presents the estimation results. Section 6 provides a discussion of our findings and concludes the paper.

\section{CONCEPTUAL FRAMEWORK}

Economic theory suggests that individuals decide to migrate by comparing their expected lifetime utility in their current location with that in alternative destinations net of costs associated with their location decision. We conceptualize the role of personality traits in this cost-benefit analysis. In doing this, we follow the line of reasoning provided by Almlund et al. (2011) and Borghans et al. (2008) who suggest that personality can be incorporated into the individual decision mechanism through constraints, preferences, and expectations.

Individuals differ in their personality traits which may lead to different constraints (Borghans et al., 2008). Having certain personality traits may constitute a constraint by affecting the costs associated with migration decisions which leads individuals to make different migration decisions and choose different locations. Migration involves both monetary and non-monetary costs that differ across alternative destinations. According to Sjaastad (1962), monetary costs represent the out-of-pocket money spent for traveling and relocation and costs of gathering information. Such costs depend on socio-economic characteristics such as education and cognitive ability. ${ }^{3}$ Non-monetary costs involve psychic costs due to leaving a familiar

\footnotetext{
${ }^{3}$ Individuals with high level of ability and education might have lower cost of gathering information and higher chance of obtaining a visa or residence permit. Schwartz (1973) showed that the negative impact of distance on migration decreases with education and interpreted this finding as the indication of informational costs being lower as skill levels increase. However, it should be noted that monetary costs can also be indirectly affected by personality traits via their impact on individual outcomes such as educational
} 
surrounding behind, building up new social relations abroad, and adaptation to a new social and cultural environment. Such costs can be determined by the same factors that affect monetary costs. For example, Bauernschuster et al. (2014) found that highly educated individuals more easily adapt to culturally different environments than those with lower educational attainments. We hypothesize that non-monetary costs are a function of personality traits. The level of psychic costs may vary across individuals since they may differently perceive these costs due to their particular personality traits.

Preferences and expectations are the other two channels through which personality traits may affect migration decision and location choice. ${ }^{4}$ If having specific traits make individuals less risk averse or less impatient, then those traits may lead to a higher likelihood of migration. ${ }^{5}$ Furthermore, migration decisions depend on how expectations about potential outcomes in alternative locations are constructed. Formation of expectations is based on how individuals perceive and process information which is affected by personality traits in different ways (Almlund et al., 2011). For instance, people more open to new experiences can gather more information (Almlund et al., 2011). Depending on their personality and how they construct their information set, individuals may well predict, inflate, or deflate the benefits expected to be obtained in alternative locations which, in turn, may affect their decision.

Considering that personality traits enter into the decision mechanism via expected benefits and/or perceived costs, we expect the following relations between the decision to migrate to culturally distant destinations and the Big Five personality traits:

Extraversion Extravert individuals are described by characteristics such as being talkative, sociable, enterprising, adventurous, and optimistic (Goldberg, 1990). Moving to another place means a person's leaving her social network behind and building up a new network in the new location. Thus, being sociable, talkative, and enterprising makes it more likely to be more willing to migrate to new social circles. Furthermore, being optimistic may make extraverts confident about their potential outcomes in the new location as they may tend to be overconfident in assessing their performance in tasks (Schaefer et al., 2004). In this respect, extraverts are expected to be more likely to migrate and this has been found in several studies (Canache et al., 2013; Jokela, 2009; Jokela et al., 2008; Silventoinen et al., 2008). Jokela et al. (2008) found that high sociability is related to moving to urban areas and longer distances although they did not

attainment. See Almlund et al. (2011) for a review of studies on predictive power of personality on education outcomes and earnings capacity.

${ }^{4}$ On the relation between risk preference and migration decisions, see Massey (1990) and Jaeger et al. (2010). For the relation between time preference and migration decisions, see Bowles (1970) and Nowotny (2014)

${ }^{5}$ As personality shapes preferences, preferences may also shape personality. Although there is no evidence on the direction of causality, literature provides correlational evidence on the relationship between personality traits and economic and social preferences. See Almlund et al. (2011) for a review. 
distinguish geographic and cultural distance. Because extraverts are more adventurous and optimistic, this could result in the fact that they perceive the psychic costs of migration to be lower or the expected utility to be higher in case of moving to a culturally distant destination.

Agreeableness This trait refers to characteristics such as being friendly, respectful, adaptable, and flexible (Goldberg, 1990). Jokela (2009) showed that more agreeable individuals are more likely to have strong ties within their community. As agreeable individuals tend to internalize the values and norms of their local community, this makes them less likely to migrate. However, once they decide to migrate, more agreeable people can perceive the psychic costs of moving to culturally distant regions to be lower. Huang et al. (2005) showed that more agreeable expatriates better integrate to the local community in their destination country. Hence, there are two opposing effects in the relation between agreeableness and migration. On the one hand, agreeable individuals may perceive costs of leaving their community behind to be higher and therefore be less likely to migrate. On the other hand, they may perceive psychic costs to be lower once they start to live in a different location, as they are more flexible and adaptable to other cultures.

Conscientiousness This trait is characterized by being organized, systematic, responsible, predictable, and conventional (Goldberg, 1990).Conscientious individuals, just like extraverts, tend to be overconfident in assessing their performance (Schaefer et al., 2004). Although this characteristic is expected to make them predict their expected utility in an alternative location to be higher, other traits associated with conscientiousness may decrease the likelihood of such individuals to migrate. As predictability and order are important to them, conscientious people may perceive the psychic costs of migration to be higher as it involves uncertainties. Moreover, Paulauskaite et al. (2010) argued that conscientious individuals are less willing to migrate as they may feel more responsible for their family and community. Therefore, we expect to find a negative association between conscientiousness and willingness to migrate. Huang et al. (2005) suggested that more conscientious expatriates are more likely to experience difficulties with integration as they perceive the new environment to be unpredictable. As cultural dissimilarity increases, unforeseen circumstances a potential migrant may experience also increase. Hence, if they migrate, conscientious people are expected to migrate to destinations that are culturally similar to their region of origin.

Emotional stability This trait is associated with characteristics such as being calm, peaceful, balanced, and confident. Neuroticism, the opposite of emotional stability, is related to being anxious, nervous, fearful, and negativistic (Goldberg, 1990). At first sight, it seems that emotionally stable individuals may be more likely to migrate as being stable and confident may make them better able at dealing with uncertainties associated with migration. However, Silventoinen et al. (2008) and Jokela et al. (2008) found a positive relation between neuroticism and migration. These findings may be driven by neurotic people having lower 
job satisfaction (Van Den Berg and Feij, 1993) and lower neighborhood satisfaction (Jokela et al., 2008). Hence, the sign of the relation between emotional stability and migration is hard to predict. Furthermore, Jokela et al. (2008) found that higher neuroticism is correlated with a lower geographical distance migrated. The authors hypothesized that neurotics may avoid long distance migration due to their tendency to feel distressed. In terms of cultural distance, two opposing effects can be expected. If proneness to anxiety and fear is dominant in neurotics, then emotionally stable individuals are expected to move to culturally more distant regions compared to neurotic individuals. However, if dissatisfaction with current location prevails in neurotics, then emotionally stable individuals may be less likely to move to culturally distant regions.

Openness to new experiences Individuals who are open to new experiences are characterized by being inventive, curious, and cosmopolitan (Goldberg, 1990). As migration is essentially an experience full of novelty in terms of location, social networks, and culture, open individuals are expected to be more willing to experience it. As in other studies (Canache et al., 2013; Jokela, 2009; Paulauskaitè et al., 2010), we therefore expect to find a positive association between migration and openness. It is also straightforward to expect a positive correlation between cultural distance and openness for at least two reasons. First, because open individuals are more curious, they may search more and construct a more accurate information set (Almlund et al., 2011) leading them to more accurately predict their utility in a different location. Second, because open individuals are curious about novelties, they may perceive psychic costs of adaptation to be lower as culturally different locations may be even more attractive to them.

In brief, we expect more extravert, less agreeable, less conscientious, and more open individuals to be more likely to report migration intentions. Furthermore, we expect more extravert, more agreeable, less conscientious, and more open individuals to move to culturally distant locations as individuals having these traits may either consider a broader choice set when making their decisions or predict a higher expected utility in case of moving to an alternative location. We do not have a clear prediction for emotional stability as the results depend on which of the opposing effects mentioned above dominates.

\section{DATA}

We use the Fachkraft data to test our hypotheses. It is a biannual survey conducted by Maastricht University in cooperation with Studitemps GmbH among students at German universities. The survey aims to gather information on general study characteristics, the part-time student job market, and students' future career expectations. Data is gathered online through 'Jobmensa' that is the largest student network in Germany for student jobs and internships and has more than 400,000 users. Questionnaires are filled in via the survey hosting service called 'FluidSurveys'. Data collection started in September 2012. We used the data from 
round six conducted in March 2015. University students using Jobmensa received an invitation via e-mail to participate to the survey. $7 \%$ of these students participated to the survey in March $2015 .{ }^{6} 61 \%$ of them completed the main questionnaire. Although participation is incentivized, the response rate is low. Nevertheless, the sample is representative for the student population: the distribution of observable characteristics in the Fachkraft data does not differ substantially from the Sozialerhebung, another largescale German survey among students having a systematic sample and conducted regularly at German universities by the government (Bergerhoff et al., 2015).

The Fachkraft survey includes a question on where university students want to work after their graduation. ${ }^{7}$ Students are provided with a binary response option where they can choose either Germany or abroad. Our first outcome variable, intention to migrate, is constructed based on the responses given to this question. This variable reflects stated preferences of students rather than their actual behavior. There are different standpoints across disciplines on how intentions relate to actual behavior. Intentions are considered as an integral part of decision making process in sociological and psychological theories of mobility (DaVanzo, 1980; Fawcett, 1985). This strand of literature assumes sequential decisions for mobility where the intention to move is followed by actual move ( $\mathrm{Lu}, 1999)$. In economics, research traditionally focuses on actual behavior rather than intentions. This is because individuals' preferences are believed to be revealed by their actual behavior but not to be fully reflected by their intentions (DaVanzo, 1980). Nevertheless, the use of stated preferences in several subfields of economics has become common as stated preferences allow to simulate market setting and to model choices by fully observing the alternatives (Sund, 2010). According to the theory of reasoned action by Fishbein and Ajzen (1975), acting depends on the intention to act which is determined by beliefs about and evaluation of the consequences of acting and one's motivation to comply with these beliefs. Especially international migration is a complex process, which requires extensive preparation to gather information regarding the destination country, to find a job and an accommodation, and to deal with bureaucratic processes such as obtaining a visa or residence permit. In this respect, intention to migrate may indicate future actual migration if it includes motivation to prepare for it. While intentions are informative for actual behavior, research shows that there is no one-to-one correspondence between intention to migrate and actual migration. Van Dalen and Henkens (2013) found that $34 \%$ of native Dutch residents who stated their willingness to emigrate actually moved abroad in the following five years after their first survey. Thus, we should note that our results should not be directly translated to realized migration.

\footnotetext{
${ }^{6}$ There are 28,064 participants in total but almost $16 \%$ of them are either high school students or persons who already graduated from university. We focus on 23,585 university students to obtain a homogeneous sample.

${ }^{7}$ The question is "Where would you like to work after the study?" (original question in German: "Wo wollen Sie nach dem Studium gerne arbeiten?").
} 
Students who stated their intention to work abroad are also asked which country they would like to move to. Using this information, we constructed our second dependent variable, cultural distance, as the cultural difference between Germany and the country of migration students indicated. Hofstede (2001) defines culture as 'collective mental programs' reflected by values and behaviors of individuals living in a society which differentiate them from the members of another society. Hofstede's initial four-dimensional taxonomy ${ }^{8}$ is based on a survey on values conducted among employees of the International Business Machines (IBM), a large multinational company, around the world between 1967 and 1973. Since then the survey (recently called Values Survey Module) has been conducted in many other countries and the most recent data is published on Hofstede's website. Hofstede's national culture dimensions are a standard in literature, and used in many research fields in psychology, sociology, international marketing, and management (Søndergaard, 1994; Steenkamp, 2001). We think that the Hofstede framework provides an appropriate measure of cultural difference for our study. Hofstede and McCrae (2004) showed that Big Five personality traits are correlated with national culture dimensions. Their findings indicate that individuals' personality is to a certain extent linked to the 'collective mental programs' of the societies they live in. In this respect, the deviation of an individual's personality traits from the average traits observed in a society may be a good predictor of how much a person is likely to move to culturally distant countries.

Following Kogut and Singh (1988), we compute the cultural distance between home country $H$, Germany, and preferred migration country $d$ as follows:

$$
\text { Cultural distance }_{i, d}=\frac{1}{4} \sum_{k=1}^{4} \frac{\left(I_{d k}-I_{H k}\right)^{2}}{V_{k}}
$$

where $I_{d k}$ represents the score of a country in each culture dimension $k=1, \ldots, 4, I_{H k}$ represents Germany's score in that dimension, and $V_{k}$ is variance of the scores in dimension $k$. This index measures the deviation of every alternative destination country from Germany in each Hofstede dimension. Then deviations are corrected for differences in the variance of dimensions to equalize the scale across dimensions for averaging.

\footnotetext{
${ }^{8}$ The initial Hofstede taxonomy includes the following dimensions: (i) Power distance index (PDI) expressing to what extent the less powerful individuals in a society expect and accept the unequal distribution of power. This dimension reflects the level of hierarchy in a society. (ii) Individualism index (IDV) measuring the degree to which individuals are responsible only for themselves and their immediate family in a society. The counterpart of it is collectivism where individuals are seen as an integral part of larger groups. (iii) Masculinity index (MAS) reflecting the distribution of emotional roles between men and women in a society. (iv) Uncertainty avoidance index (UAI) expressing to what extent the members of a society tolerate unexpected and unstructured situations. Later, two other dimensions are also added which are long-term vs. short-term orientation and indulgence vs. restraints. The detailed descriptions for all dimensions can be found in Hofstede (2001) and Hofstede and Hofstede (2015, December 08). We did not include the last two dimensions when constructing our cultural distance variable since index values for these dimensions are only available for a limited number of countries.
} 
The Fachkraft survey includes the fifty item IPIP Big Five personality test based on Goldberg (1992) and Goldberg et al. (2006). Participating into this part of the survey is optional. 52\% of students who responded the main part of the survey also participated to the personality test. Our key independent variables are the students' scores in five dimensions of personality constructed as follows: There are ten items for each personality traits consisting five 'positive keyed' and five 'negative keyed' items that represent two poles of a trait. ${ }^{9}$ Students are asked to assess to what extent a given item reflects their personality on a five-point Likert scale ranging from very inaccurate to very accurate. This scale is scored from one to five for positive keyed items and from five to one for negative keyed items. We obtained students' total scale score by summing all score numbers assigned to each item in the test. ${ }^{10}$ In our analysis, we use students' personality scores standardized to mean 0 and standard deviation 1 . Besides, we included a range of control variables in our analyses that we selected based on the previous migration literature. ${ }^{11}$ Table A1 provides the description of our dependent and independent variables.

$13 \%$ of university students do not have a German passport. Foreign students studying in Germany might be willing to return to their home countries after they complete their study program. For this reason, we restricted our analysis to students who have a German passport. ${ }^{12}$ Our final estimation sample includes 8,572 students. Summary statistics for all variables are provided in Table A2. Table A3 provides further descriptive statistics for students' preferred destinations and their geographic, economic, and cultural distance from Germany.

Table A4 shows the mean personality traits of students who intend and do not intend to migrate. As expected, students who have an intention to move abroad are more extravert, less agreeable, less conscientious, less emotionally stable, and more open compared to students who have the intention to stay in Germany. The table also shows differences in personality for students with a migration intention by cultural distance to Germany. Contrary to expectations, we find that students who are willing to move to culturally distant countries significantly have lower levels of extraversion than students that are willing to move to countries more similar to Germany in terms of culture. They do score higher on agreeableness as

\footnotetext{
${ }^{9}$ For instance, the item "Don't mind being the center of attention" is a positive keyed item for extraversion. The item "Don't like to draw attention to myself" is a negative keyed item for the same trait but it represents the opposite pole that is introversion.

${ }^{10}$ We followed the methodology suggested on IPIP website.

${ }^{11}$ For age and sex, see, e.g., Faggian et al. (2007), Coniglio and Prota (2008), and Venhorst et al. (2010). For marriage and risk attitude, see, e.g., Jaeger et al. (2010) and Bauernschuster et al. (2014). For immigrant background and study-related characteristics such as GPA and study field, see e.g. De Grip et al. (2010). In our cultural distance models, we included geographic distance, difference of GDP level between Germany and intended destination country, and free mobility dummy to neutralize the geographic, economic, and bureaucratic factors behind migration decision.

12467 students who do not have a German passport stated their willingness to work abroad after their graduation. However, when their intended destination country is crosschecked with their nationality, we observe that $36 \%$ of them expressed a willingness to work in their home countries. Inclusion of these students may confound our analysis since we defined cultural distance by taking Germany as the reference point.
} 
expected. In addition, students who are willing to move to culturally distant countries are significantly less conscientious and less emotionally stable. They seem to be more open but differences between groups are not significant.

\section{EMPIRICAL STRATEGY}

We performed two types of regression analyses to test our hypotheses. First, we estimate a probit regression (equation 2) where our dependent variable is intention to migrate, and report marginal effects. We expect to find significant $\beta^{\prime}$ s for each personality trait $j$ in the directions explained in Section 2. We control for risk and time preferences, socio-demographic characteristics such as age, sex, relationship status, and immigrant background and study-related characteristics such as GPA, and level and field of study.

$$
\begin{aligned}
& \text { Intention to migrate }_{i}=\alpha+\beta_{j} *{\text { Personality } \text { traits }_{i j}+\gamma * \text { Controls }_{i}+\varepsilon_{i}}_{\text {Cultural distance }_{i, d}=\delta+\theta_{j} * \text { Personality traits }_{i j}+\mu * \text { Controls }_{i}+\lambda *} \\
& \text { Controls }_{d}+u_{i} \quad(d \neq H)
\end{aligned}
$$

In our second model (equation 3), the dependent variable is cultural distance (equation 1) between Germany's and each potential destination country, which we estimate using OLS for the sample of students who report a migration intention. We expect to find significant $\theta$ s for each personality trait $j$ with signs in the direction explained in Section 2. In this model, we control for a set of students' socio-demographic and study-related characteristics that can be relevant for cultural distance such as age, sex, and GPA in addition to risk and time preferences. We additionally control for geographic distance, differences in GDP, and a dummy to capture free mobility to the destination country, to isolate geographic, economic, and bureaucratic factors affecting destination choice.

\section{RESULTS}

\subsection{Migration intentions}

Estimation results of probit models for intention to migrate are presented in Table A6. Focusing on the results in Column 6, one standard deviation increase in extraversion (6.5 points) and openness (4.8 points) are associated with $1.1 \%$ and $2.2 \%$ increase in the probability of intending to migrate, respectively. ${ }^{13}$ These estimates account for approximately $0.9 \%$ and $2.4 \%$ of the unconditional probability of intending to migrate observed in the sample (19\%) for one point increase in extraversion and openness, respectively. Conversely,

${ }^{13}$ Unstandardized scores of Big 5 personality traits are presented in Table A9. 
one standard deviation increase in agreeableness (5.1 points) and conscientiousness (5.6 points) are correlated with $2.5 \%$ and $2.2 \%$ decrease in the probability of intending to migrate. These account for $2.6 \%$ and $2.1 \%$ of unconditional probability for one unit change in these two traits, respectively. Moreover, we find that one standard deviation increase in emotional stability (6.6 points) is associated with $1.3 \%$ decrease in probability of intending to migrate. One unit change in this trait is related to $1 \%$ change in the probability of intending to migrate over the unconditional probability.

Our estimates for intention to migrate in Table A6 show that one standard deviation increase in risk aversion is associated with around 5\% decrease in likelihood of having migration intention. Unlike risk preferences, we do not find a robust significant association of time preferences with intention to migrate. Although inclusion of risk attitude improves the explanatory power of our model (compare Column 2 to Column 1), it hardly changes the magnitude of our estimates for personality traits except extraversion. It is in line with Becker et al. (2012) showing that risk preferences and personality traits are complementary in explaining individuals' labor market success, health status, and life satisfaction.

Inclusion of demographic and study-related characteristics in our model for intention to migrate do not significantly change the marginal effects estimated for personality traits and risk aversion (compare Column 4 and 6 to Column 2). Younger students and students with immigrant background in our sample are more likely to have migration intentions while students who have a stable relationship are less likely to consider starting a career abroad. Female students consider starting a career abroad more than male students. This finding coincides with recent trends in international migration flows that more skilled women have been internationally mobile for career purposes (Docquier et al., 2009). We unexpectedly find that students with a higher GPA are less likely to have migration intentions. $\mathrm{PhD}$ students tend to have migration intentions more than undergraduate students while the opposite is observed for master's students. Migration intentions tend to vary by field of study as well. For example, compared to economics students, students studying in mathematics and engineering fields are less likely to have migration intentions. Students in STEM fields might be more willing to stay in their home country after their graduation as they may perceive labor market conditions in Germany more favorable considering skill shortages in the German labor market (Bellmann and Hübler, 2014).

\subsection{Cultural distance}

Results of OLS estimation for our cultural distance model on the sample of students who express a migration intention are presented in Table A7. Column 1 shows that one standard deviation increase in openness ( 4.9 points for students who have a migration intention) is associated with 0.045 units increase in 
the cultural distance that German students are willing to migrate. It accounts for $0.9 \%$ of unconditional mean of cultural distance ( 0.982 units). Unlike openness, conscientiousness is negatively associated with cultural distance that German students intend to migrate. However, it is not significant when we include our controls. Contrary to our hypothesis, we find that extraversion is negatively associated with cultural distance, and propose an explanation for this in Section 5.3 where we investigate migration to German-, English- and other-speaking countries as an alternative measure to cultural distance.

As Table A7 further shows, increase in risk aversion is negatively associated with cultural distance that German students are willing to migrate but coefficients are not significant at any standard significance level. Similarly, we do not find a robust significant association of cultural distance that students are willing to migrate with their time preferences, age, gender, and GPA. Inclusion of country-specific characteristics (Column 5) significantly improves the explanatory power of our model but does not alter the correlations we find for extraversion and openness.

\subsection{Language distance}

German students in our sample who intend to start a career abroad mostly prefer English or German speaking countries. These countries to a certain extent share common cultural characteristics as reflected by pairwise correlations between Hofstede cultural distance index and language dummies in Table A5. Hence, we use country-language groups as an imperfect substitute for Hofstede cultural distance index to check the robustness of our main finding. We defined a categorical variable taking 0 for German-speaking countries, 1 for English-speaking countries, and 2 for other countries and replicated our analysis for cultural distance. Results of multinomial logit estimation are presented in Table A8.

We find that extravert students are significantly less likely to prefer non-German/non-English-speaking countries as potential migration destinations. One standard deviation increase in extraversion is related to $2.4 \%$ decline in likelihood of having intention to migrate to a non-German/non-English-speaking country after controlling for risk and time preferences, demographic and study-related characteristics, and countryspecific characteristics. These estimates provide further insights that we do not capture in our main analysis. Students scoring higher on agreeableness are more likely to prefer non-German/non-English-speaking countries as one standard deviation increase in agreeableness is associated with $2 \%$ increase in having a preference over non-German/non-English-speaking countries. Furthermore, students scoring higher in conscientiousness are more likely to prefer German-speaking countries as migration destinations. One standard deviation increase in conscientiousness is associated with $1.1 \%$ increase in likelihood of considering a German-speaking country as a potential destination. 


\section{CONCLUSION}

In this paper, we investigate whether personality traits are related to individuals' international migration intentions and preferences over alternative destination countries with different cultural background. We use the Fachkraft survey with information on German university students' migration intentions after they graduate, their preferred destination country, and their Big Five personality traits. The results confirm our hypotheses that more open and extravert students are more likely to consider moving abroad while more conscientious and agreeable students are less inclined to migrate. We find that more emotionally stable students are less likely to have migration intentions. This suggests that emotionally stable individuals are more satisfied with their current location and community, making them less likely to develop migration intentions. Such an interpretation is in line with findings from Jokela et al. (2008), Silventoinen et al. (2008), and Van Den Berg and Feij (1993).

With respect to cultural distance, we find that openness positively and extraversion negatively relate to the willingness to move to countries that are culturally more remote. This holds even when we control for risk attitude, time preference, personal characteristics, geographic distance and economic differences between countries. This suggests an independent relation between personality and cultural distance of migration. Although the correlation with respect to openness is as expected, this does not hold for extraversion. Using language distance as an alternative to cultural distance, we show that extraverts are more likely to consider countries where German or English are official languages. It explains why we observe a negative association of cultural distance with extraversion in our main analyses. We also find that more agreeable students are more likely to consider non-German/non-English-speaking countries as potential destinations when we use language as a cultural distance indicator. Although there is a consensus in migration psychology literature on that extraverts are more likely to migrate, evidence on their location choice is not straightforward. Jokela et al. (2008) find that highly sociable (i.e., extravert) individuals are more likely to migrate longer distances and to prefer urban areas while Jokela (2009) finds that higher extraversion predicts higher migration flows within but not between states in the US. Ayhan et al. (2017) found a negative relation between extraversion and propensity to migrate from rural areas to cities and explain this finding by social individuals' feeling more attached to their own communities. We think that in our case, extraverts perceive their utility being lower in linguistically distant countries where they may not easily involve in social interactions. Hence, they prefer countries where they can easily overcome language barrier.

Our results suggest a positive self-selection of immigrants in terms of openness as individuals who are more open to new experiences may integrate into their host countries more easily and faster. However, 
immigrants are negatively self-selected in terms of conscientiousness which may indicate a slower economic integration process particularly in the job market considering conscientiousness is often associated with higher job performance (Almlund et al., 2011). Furthermore, we find that immigrants may sort themselves into countries where they can easily integrate as indicated by our findings for extravert and agreeable individuals' preferences over linguistic characteristics of countries. 


\section{REFERENCES}

Almlund, M., Duckworth, A. L., Heckman, J., \& Kautz, T. (2011). Personality psychology and economics. In E. A. Hanushek, S. Machin, \& L. Woessmann (Eds.), Handbook of the Economics of Education (Vol. 4, pp. 1-181): Elsevier.

Ayhan, S., Gatskova, K., \& Lehmann, H. (2017). The impact of non-cognitive skills and risk preferences on rural-to-urban migration: Evidence from Ukraine. IZA Discussion Paper Series No.10982.

Bauernschuster, S., Falck, O., Heblich, S., Suedekum, J., \& Lameli, A. (2014). Why are educated and riskloving persons more mobile across regions? Journal of Economic Behavior \& Organization, 98, 56-69.

Becker, A., Deckers, T., Dohmen, T., Falk, A., \& Kosse, F. (2012). The relationship between economic preferences and psychological personality measures. Annual Review of Economics, 4(1), 453-478.

Bellmann, L., \& Hübler, O. (2014). The skill shortage in German establishments before, during and after the Great Recession. In Jahrbücher für Nationalökonomie und Statistik (Vol. 234, pp. 800).

Belot, M., \& Ederveen, S. (2012). Cultural barriers in migration between OECD countries. Journal of Population Economics, 25(3), 1077-1105.

Bergerhoff, J., Hartmann, S., \& Seegers, P. K. (2015). Fachkraft 2020: Erhebung zur wirtschaftlichen und allgemeinen Lebenssituation der Studierenden in Deutschland im WS 2013/2014 und SS 2014. Retrieved from Cologne/Maastricht:

Bertoli, S., Fernández-Huertas Moraga, J., \& Ortega, F. (2013). Crossing the border: Self-selection, earnings and individual migration decisions. Journal of Development Economics, 101, 75-91.

Borghans, L., Duckworth, A. L., Heckman, J. J., \& Weel, B. t. (2008). The economics and psychology of personality traits. Journal of Human Resources, 43(4), 972-1059.

Bowles, S. (1970). Migration as investment: Empirical tests of the human investment approach to geographical mobility. The Review of Economics and Statistics, 52(4), 356-362.

Bütikofer, A., \& Peri, G. (2017). Cognitive and noncognitive skills and the selection and sorting of migrants. National Bureau of Economic Research Working Paper Series, No. 23877.

Camperio Ciani, A. S., Capiluppi, C., Veronese, A., \& Sartori, G. (2007). The adaptive value of personality differences revealed by small island population dynamics. European Journal of Personality, 21(1), $3-22$.

Canache, D., Hayes, M., Mondak, J. J., \& Wals, S. C. (2013). Openness, extraversion and the intention to emigrate. Journal of Research in Personality, 47(4), 351-355.

Coniglio, N. D., \& Prota, F. (2008). Human capital accumulation and migration in a peripheral EU region: the case of Basilicata. Papers in Regional Science, 87(1), 77-95.

Czaika, M. (2012). Migration in times of uncertainty: on the role of economic prospects. DEMIG project paper no. 11. International Migration Institute. 
DaVanzo, J. (1980). Micro economic approaches to studying migration decisions. In (pp. 56pp.).

De Grip, A., Fouarge, D., \& Sauermann, J. (2010). What affects international migration of European science and engineering graduates? Economics of Innovation and New Technology, 19(5), 407-421.

Docquier, F., Lowell, B. L., \& Marfouk, A. (2009). A gendered assessment of highly skilled emigration. Population and Development Review, 35(2), 297-321.

Faggian, A., McCann, P., \& Sheppard, S. (2007). Some evidence that women are more mobile than men: Gender differences in U.K. graduate migration behavior Journal of Regional Science, 47(3), 517539.

Fawcett, J. T. (1985). Migration psychology: New behavioral models. Population and Environment, 8(1), 5-14.

Fishbein, M., \& Ajzen, I. (1975). Belief, attitudes, intention and behavior: an introduction to theory and research. Reading, MA: Addison-Wesley Publishing Company.

Goldberg, L. R. (1990). An alternative "description of personality": the big-five factor structure. Journal of Personality and Social Psychology, 59(6), 1216-1229.

Goldberg, L. R. (1992). The development of markers for the Big-Five factor structure. Psychological Assessment, 4(1), 26-42.

Goldberg, L. R., Johnson, J. A., Eber, H. W., Hogan, R., Ashton, M. C., Cloninger, C. R., \& Gough, H. G. (2006). The international personality item pool and the future of public-domain personality measures. Journal of Research in Personality, 40(1), 84-96.

Groenewold, G., Bruijn, B., \& Bilsborrow, R. (2012). Psychosocial factors of migration: Adaptation and application of the health belief model. International Migration, 50(6), 211-231.

Hofstede, G. (2001). Culture's consequences: comparing values, behaviors, institutions, and organizations across nations. Thousand Oaks, Sage Publications: Sage Publications.

Hofstede, G., \& Hofstede G. J. (2015, December 08). Dimension data matrix (version 20151208). Retrieved from http://geerthofstede.com/research-and-vsm/dimension-data-matrix/

Hofstede, G., \& McCrae, R. R. (2004). Personality and culture revisited: Linking traits and dimensions of culture. Cross-Cultural Research, 38(1), 52-88.

Huang, T. J., Chi, S. C., \& Lawler, J. J. (2005). The relationship between expatriates' personality traits and their adjustment to international assignments. The International Journal of Human Resource Management, 16(9), 1656-1670.

Jaeger, D. A., Dohmen, T., Falk, A., Huffman, D., Sunde, U., \& Bonin, H. (2010). Direct evidence on risk attitudes and migration. Review of Economics and Statistics, 92(3), 684-689.

John, O. P., Naumann, L. P., \& Soto, C. J. (2008). Paradigm shift to the integrative Big Five trait taxonomy: History, measurement, and conceptual issues. In Handbook of personality: Theory and research, $3 r d$ ed. (pp. 114-158). New York, NY, US: Guilford Press. 
Jokela, M. (2009). Personality predicts migration within and between U.S. states. Journal of Research in Personality, 43(1), 79-83.

Jokela, M., Elovainio, M., Kivimäki, M., \& Keltikangas-Järvinen, L. (2008). Temperament and migration patterns in Finland. Psychological Science, 19(9), 831-837.

Kogut, B., \& Singh, H. (1988). The effect of national culture on the choice of entry mode. Journal of International Business Studies, 19(3), 411-432.

Lu, M. (1999). Do people move when they say they will? Inconsistencies in individual migration behavior. Population and Environment, 20(5), 467-488.

Massey, D. S. (1990). Social structure, household strategies, and the cumulative causation of migration. Population Index, 56(1), 3-26.

Massey, D. S., Arango, J., Hugo, G., Kouaouci, A., Pellegrino, A., \& Taylor, J. E. (1993). Theories of international migration: A review and appraisal. Population and Development Review, 19(3), 431466.

Mayda, A. M. (2010). International migration: a panel data analysis of the determinants of bilateral flows. Journal of Population Economics, 23(4), 1249-1274.

Murray, G., Judd, F., Jackson, H., Fraser, C., Komiti, A., Hodgins, G., Pattison, P., Humphreys, J., Robins, G. (2005). The five factor model and accessibility/remoteness: Novel evidence for personenvironment interaction. Personality and Individual Differences, 39(4), 715-725.

Nowotny, K. (2014). Cross-border commuting and migration intentions: The roles of risk aversion and time preference. Contemporary Economics, 8(2), 137-156.

Paulauskaitè, E., Šeibokaitè, L., \& Endriulaitienè, A. (2010). Big five personality traits linked with migratory intentions in Lithuanian student sample. International Journal of Psychology: A Biopsychosocial Approach, 7, 41-58.

Pedersen, P. J., Pytlikova, M., \& Smith, N. (2008). Selection and network effects-Migration flows into OECD countries 1990-2000. European Economic Review, 52(7), 1160-1186.

Schaefer, P. S., Williams, C. C., Goodie, A. S., \& Campbell, W. K. (2004). Overconfidence and the Big Five. Journal of Research in Personality, 38(5), 473-480.

Schwartz, A. (1973). Interpreting the effect of distance on migration. Journal of Political Economy, 81(5), 1153-1169.

Silventoinen, K., Hammar, N., Hedlund, E., Koskenvuo, M., Rönnemaa, T., \& Kaprio, J. (2008). Selective international migration by social position, health behaviour and personality. European Journal of Public Health, 18(2), 150-155.

Sjaastad, L. A. (1962). The costs and returns of human migration. Journal of Political Economy, 70(5), 8093.

Søndergaard, M. (1994). Research note: Hofstede's consequences: A study of reviews, citations and replications. Organization Studies, 15(3), 447-456. 
Steenkamp, J. B. E. M. (2001). The role of national culture in international marketing research. International Marketing Review, 18(1), 30-44.

Sund, B. (2010). Economic evaluation, value of life, stated preference methodology and determinants of risks. Örebro University,

Van Dalen, H. P., \& Henkens, K. (2013). Explaining emigration intentions and behaviour in the Netherlands, 2005-10. Population Studies, 67(2), 225-241.

Van Den Berg, P. T., \& Feij, J. A. (1993). Personality traits and job characteristics as predictors of job experiences. European Journal of Personality, 7(5), 337-357.

Venhorst, V., Van Dijk, J., \& Van Wissen, L. (2010). Do the best graduates leave the peripheral areas of the Netherlands? . Tijdschrift voor Economische en Sociale Geografie, 101(5), 521-537.

Wang, Z., De Graaff, T., \& Nijkamp, P. (2016). Cultural diversity and cultural distance as choice determinants of migration destination. Spatial Economic Analysis, 11(2), 176-200.

World Bank. (2016, September 08). World Development Indicators. Retrieved from http://data.worldbank.org/products/wdi 


\title{
APPENDIX
}

\section{Table A1: Dependent and independent variables}

\author{
Dependent variables \\ Intention to migrate \\ Cultural distance \\ Country where a student intends to start a career after finishing her studies \\ Binary variable: 0 if Germany, 1 if abroad \\ Cultural difference between Germany and a student's preferred destination country to \\ work \\ Continuous variable measured by a composite index constructed through four \\ Hofstede national culture dimensions based on the formula of Kogut and Singh \\ (1988) \\ Language distance \\ Country where a student intends to start a career after finishing her studies \\ Categorical variable: 0 if a student intends to move one of the German- speaking \\ countries (Austria, Belgium, Luxembourg, Switzerland), 1 if a student intends to \\ move one of the English-speaking countries (Australia, Canada, Ireland, New \\ Zealand, UK, USA), 2 otherwise \\ Key independent variables \\ Big Five personality traits ${ }^{\mathrm{a}}$ \\ Extraversion \\ Agreeableness \\ Conscientiousness \\ Emotional stability \\ Openness \\ Control variables \\ Risk aversion \\ Impatience \\ Age \\ Female \\ Having a stable relation \\ Immigrant background \\ Measured by 50-item IPIP inventory (all are standardized continuous variables) \\ Having an energetic approach towards social and material world \\ Having a prosocial and communal orientation towards others with antagonism \\ Having a socially prescribed impulse control that facilitates task- and goal-directed \\ behavior \\ Contrasting with neuroticism associated with proneness to feel anxious, nervous, \\ sad, and tense \\ The breadth, depth, originality, and complexity of an individual's mental and \\ experiential life \\ Standardized continuous variable (increase in the variable indicates increase in risk \\ aversion.) \\ Standardized continuous variable (increase in the variable indicates increase in \\ impatience.) \\ Age of students in years, continuous variable \\ Binary variable: 0 if male (base group), 1 if female \\ Relationship status of the student (base group: no relationship) \\ Binary variable: 1 if student has a stable relationship or is married, 0 otherwise \\ Whether a student has at least one foreign-born parent \\ Binary variable: 0 if both parents have German passport, 1 otherwise \\ GPA \\ Level of study \\ Indicator of academic success, measured by grade point average at the time of the \\ survey \\ Categorical variable for the degree followed: 0 if Bachelor's (base group), 1 if \\ Master's, 2 if $\mathrm{PhD}$ \\ Study field \\ Categorical variable for study fields: \\ Education, computer sciences, engineering sciences, art \& music, mathematics, \\ media \& communication, medical sciences, natural sciences, psychology, law, \\ religion, social sciences \& humanities, sports, language \& culture, economics (base \\ group) \\ Geographic distance ${ }^{b}$ \\ Distance between central points of Germany and a student's preferred destination \\ country measured in 1,000 kilometers \\ Diff GDP level ${ }^{c}$ \\ Log difference between a student's preferred destination country's and Germany's \\ average GDP per capita in the period 2010-2014 \\ Free mobility \\ Dummy variable taking 1 if a student intends to move one of the EU member countries, \\ 0 otherwise \\ Notes: ${ }^{a}$ Definitions of traits are taken from John et al. (2008) \\ ${ }^{\mathrm{b}}$ Calculated using geodist command in Stata which uses a mathematical model of the earth to calculate the length of the \\ shortest curve between two points. \\ ' Data is retrieved from World Bank's World Development Indicators (2016, September 08).
}




\section{Table A2: Summary statistics}

\begin{tabular}{|c|c|c|c|c|c|}
\hline Variable & $\mathbf{N}$ & Mean & Std. Dev. & Min & Max \\
\hline \multicolumn{6}{|l|}{ Dependent variables } \\
\hline Intention to migrate & 8,572 & 0.191 & 0.393 & 0 & 1 \\
\hline Cultural distance (Hofstede) & 1,638 & 0.982 & 0.904 & 0.033 & 4.589 \\
\hline Language distance & 1,638 & 1.306 & 0.649 & 0 & 2 \\
\hline German-speaking country & 171 & 0.104 & & & \\
\hline English-speaking country & 795 & 0.485 & & & \\
\hline Other countries & 672 & 0.410 & & & \\
\hline \multicolumn{6}{|l|}{ Big 5 personality traits } \\
\hline Extraversion & 8,572 & 0 & 1 & -2.701 & 2.647 \\
\hline Agreeableness & 8,572 & 0 & 1 & -4.924 & 1.940 \\
\hline Conscientiousness & 8,572 & 0 & 1 & -3.355 & 2.738 \\
\hline Emotional stability & 8,572 & 0 & 1 & -2.524 & 2.780 \\
\hline Openness & 8,572 & 0 & 1 & -3.874 & 2.562 \\
\hline \multicolumn{6}{|l|}{ Controls } \\
\hline Risk aversion & 8,572 & 0 & 1 & -2.513 & 3.330 \\
\hline Impatience & 8,572 & 0 & 1 & -2.434 & 3.165 \\
\hline Age & 8,572 & 22.24 & 2.862 & 17 & 30 \\
\hline Female & 8,572 & 0.599 & 0.490 & 0 & 1 \\
\hline Having a stable relation & 8,572 & 0.559 & 0.497 & 0 & 1 \\
\hline Immigrant background & 8,572 & 0.183 & 0.387 & 0 & 1 \\
\hline GPA & 8,572 & 3.704 & 1.462 & 1 & 8 \\
\hline Level of study ${ }^{a}$ & 8,477 & 0.310 & 0.475 & 0 & 2 \\
\hline Bachelor's & 5,900 & 0.696 & & & \\
\hline Master's & 2,526 & 0.298 & & & \\
\hline $\mathrm{PhD}$ & 51 & 0.006 & & & \\
\hline Study field ${ }^{\mathrm{a}}$ & 8,572 & 8.972 & 4.902 & 1 & 15 \\
\hline Education & 367 & 0.043 & & & \\
\hline Computer sciences & 492 & 0.057 & & & \\
\hline Engineering sciences & 1,289 & 0.150 & & & \\
\hline Art \& Music & 228 & 0.027 & & & \\
\hline Mathematics & 183 & 0.021 & & & \\
\hline Media \& Communication & 486 & 0.057 & & & \\
\hline Medical sciences & 348 & 0.041 & & & \\
\hline Natural sciences & 807 & 0.094 & & & \\
\hline Psychology & 260 & 0.030 & & & \\
\hline Law & 384 & 0.045 & & & \\
\hline Religion & 54 & 0.006 & & & \\
\hline Social sciences \& Humanities & 969 & 0.113 & & & \\
\hline Sports & 99 & 0.012 & & & \\
\hline Language \& Culture & 727 & 0.085 & & & \\
\hline Economics & 1,879 & 0.219 & & & \\
\hline Geographic distance & 1,638 & 4.763 & 4.522 & 0.333 & 18.31 \\
\hline Diff GDP level & 1,638 & -0.170 & 0.719 & -3.392 & 0.859 \\
\hline Free mobility & 1,638 & 0.345 & 0.476 & 0 & 1 \\
\hline
\end{tabular}

Source: Authors' tabulation

Notes: ${ }^{a}$ Mean values of sub-categories of language distance, level of study, and study field represent percentage distribution of sub-categories in the sample. 
Table A3: Descriptive statistics of students' preferred destination countries

\begin{tabular}{|c|c|c|c|c|}
\hline Country & \# Students & Cultural distance & Geographic distance & Diff GDP \\
\hline Argentina & 13 & 0.549 & 12.035 & -1.296 \\
\hline Australia & 93 & 0.328 & 14.263 & 0.199 \\
\hline Austria & 40 & 0.489 & 0.460 & 0.090 \\
\hline Belgium & 15 & 0.968 & 0.415 & 0.020 \\
\hline Brazil & 13 & 1.209 & 9.119 & -1.328 \\
\hline Bulgaria & 1 & 1.851 & 1.497 & -1.828 \\
\hline Canada & 75 & 0.339 & 6.254 & 0.114 \\
\hline Chile & 6 & 2.393 & 12.468 & -1.148 \\
\hline China & 47 & 2.527 & 7.540 & -2.109 \\
\hline Colombia & 9 & 1.858 & 9.249 & -1.857 \\
\hline Costa Rica & 1 & 2.694 & 9.452 & -1.631 \\
\hline Croatia & 3 & 1.801 & 0.796 & -1.161 \\
\hline Czech Republic & 3 & 0.380 & 0.389 & -0.780 \\
\hline Denmark & 42 & 2.642 & 0.434 & 0.284 \\
\hline Ecuador & 3 & 2.435 & 10.000 & -2.146 \\
\hline Estonia & 1 & 0.923 & 1.302 & -0.980 \\
\hline Finland & 18 & 1.109 & 1.829 & 0.058 \\
\hline France & 54 & 1.133 & 0.738 & -0.056 \\
\hline Greece & 2 & 1.781 & 1.828 & -0.603 \\
\hline Guatemala & 1 & 4.589 & 9.373 & -2.710 \\
\hline Hungary & 2 & 0.589 & 0.801 & -1.181 \\
\hline India & 8 & 1.423 & 6.559 & -3.344 \\
\hline Indonesia & 1 & 2.545 & 11.042 & -2.543 \\
\hline Iran & 5 & 0.935 & 4.086 & -1.968 \\
\hline Ireland & 43 & 0.427 & 1.272 & 0.135 \\
\hline Israel & 11 & 0.683 & 2.980 & -0.310 \\
\hline Italy & 29 & 0.207 & 0.936 & -0.223 \\
\hline Japan & 35 & 1.264 & 9.076 & 0.003 \\
\hline Latvia & 1 & 2.251 & 1.147 & -1.227 \\
\hline Luxembourg & 10 & 0.218 & 0.333 & 0.859 \\
\hline Malaysia & 2 & 3.755 & 10.738 & -1.494 \\
\hline Malta & 1 & 0.926 & 1.720 & -0.779 \\
\hline Mexico & 18 & 1.820 & 9.402 & -1.554 \\
\hline Morocco & 5 & 0.949 & 2.846 & -2.668 \\
\hline Netherlands & 51 & 1.971 & 0.366 & 0.145 \\
\hline New Zealand & 25 & 0.305 & 18.309 & -0.221 \\
\hline Norway & 34 & 2.389 & 1.994 & 0.708 \\
\hline Panama & 1 & 3.728 & 9.389 & -1.544 \\
\hline Peru & 6 & 2.131 & 10.386 & -2.065 \\
\hline Philippines & 2 & 2.543 & 10.263 & -2.933 \\
\hline Poland & 7 & 0.942 & 0.618 & -1.179 \\
\hline Portugal & 1 & 2.579 & 1.916 & -0.693 \\
\hline Romania & 3 & 2.831 & 1.234 & -1.615 \\
\hline Russia & 8 & 3.106 & 4.625 & -1.350 \\
\hline Singapore & 15 & 3.369 & 10.137 & 0.123 \\
\hline Slovenia & 3 & 3.080 & 0.654 & -0.632 \\
\hline South Africa & 11 & 0.223 & 9.092 & -1.753 \\
\hline South Korea & 11 & 2.001 & 8.546 & -0.625 \\
\hline Spain & 66 & 0.946 & 1.598 & -0.376 \\
\hline Sweden & 72 & 3.106 & 1.428 & 0.193 \\
\hline Switzerland & 106 & 0.033 & 0.483 & 0.545 \\
\hline Thailand & 8 & 2.059 & 8.725 & -2.087 \\
\hline Turkey & 31 & 1.357 & 2.363 & -1.391 \\
\hline United Kingdom & 226 & 0.597 & 0.891 & -0.105 \\
\hline United States of America & 333 & 0.423 & 7.862 & 0.128 \\
\hline Venezuela & 2 & 2.464 & 8.484 & -1.130 \\
\hline Vietnam & 5 & 2.563 & 9.100 & -3.392 \\
\hline
\end{tabular}

Source: Authors' tabulation

Notes: First column represents number of students who prefer moving to the countries listed (57 countries). The other columns show the cultural distance, geographic distance, and difference in GDP level between Germany and the countries listed, respectively. 
Table A4: Mean values of personality traits across students

\begin{tabular}{|c|c|c|c|c|c|c|}
\hline & \multicolumn{3}{|c|}{ Intention to migrate } & \multicolumn{3}{|c|}{ Cultural distance } \\
\hline & No & Yes & Diff & Low & High & Diff \\
\hline \multicolumn{7}{|l|}{ Big 5 personality traits } \\
\hline Extraversion & -0.014 & 0.061 & $\begin{array}{l}-0.075^{* * * *} \\
(0.028)\end{array}$ & 0.028 & -0.045 & $\begin{array}{l}0.073 * \\
(0.051)\end{array}$ \\
\hline Agreeableness & 0.026 & -0.110 & $\begin{array}{l}0.136 * * * \\
(0.027)\end{array}$ & -0.027 & 0.043 & $\begin{array}{l}-0.070^{*} \\
(0.051)\end{array}$ \\
\hline Conscientiousness & 0.025 & -0.107 & $\begin{array}{l}0.132 * * * \\
(0.027)\end{array}$ & 0.061 & -0.097 & $\begin{array}{l}0.158^{* * *} \\
(0.051)\end{array}$ \\
\hline Emotional stability & 0.017 & -0.070 & $\begin{array}{l}0.087^{\star * *} \\
(0.028)\end{array}$ & 0.028 & -0.045 & $\begin{array}{l}0.073^{*} \\
(0.051)\end{array}$ \\
\hline Openness & -0.024 & 0.102 & $\begin{array}{l}-0.126^{* * * *} \\
(0.027)\end{array}$ & -0.001 & 0.001 & $\begin{array}{l}-0.002 \\
(0.051)\end{array}$ \\
\hline Observations & 6,934 & 1,638 & & 1,009 & 629 & \\
\hline
\end{tabular}

Source: Authors' tabulation

Notes: Standardized scores of personality traits are reported. High (low) cultural distance refers to being above (below) median value observed in the sample. Differences at means are significant at $* * * \mathrm{p}<0.01, * * \mathrm{p}<0.05$, $* \mathrm{p}<0.1$. 
Table A5: Pairwise correlations of characteristics of students' preferred destination countries

\begin{tabular}{|c|c|c|c|c|c|c|}
\hline & $\begin{array}{l}\text { Cultural } \\
\text { distance }\end{array}$ & $\begin{array}{l}\text { Geographic } \\
\text { distance }\end{array}$ & $\begin{array}{l}\text { Diff } \\
\text { level }\end{array}$ & $\begin{array}{l}\text { Free } \\
\text { mobility }\end{array}$ & $\begin{array}{l}\text { English } \\
\text { speaking } \\
\text { country }\end{array}$ & $\begin{array}{l}\text { German } \\
\text { speaking } \\
\text { country }\end{array}$ \\
\hline Cultural distance (Hofstede) & 1.0000 & & & & & \\
\hline Geographic distance & $\begin{array}{l}0.2317 \\
0.0829\end{array}$ & 1.0000 & & & & \\
\hline Diff GDP level & $\begin{array}{l}-0.3930 * \\
0.0025\end{array}$ & $\begin{array}{l}-0.3814 * \\
0.0034\end{array}$ & 1.0000 & & & \\
\hline Free mobility & $\begin{array}{l}-0.1559 \\
0.2468\end{array}$ & $\begin{array}{l}-0.7903 * \\
0.0000\end{array}$ & $\begin{array}{l}0.4564 * \\
0.0004\end{array}$ & 1.0000 & & \\
\hline English-speaking country & $\begin{array}{l}-0.3994 * \\
0.0021\end{array}$ & $\begin{array}{l}0.2147 \\
0.1087\end{array}$ & $\begin{array}{l}0.3406 * \\
0.0095\end{array}$ & $\begin{array}{l}-0.2925^{*} \\
0.0272\end{array}$ & 1.0000 & \\
\hline German-speaking country & $\begin{array}{l}-0.3138 * \\
0.0175\end{array}$ & $\begin{array}{l}-0.2916^{*} \\
0.0278\end{array}$ & $\begin{array}{l}0.3618^{*} \\
0.0057\end{array}$ & $\begin{array}{l}0.3221 * \\
0.0145\end{array}$ & $\begin{array}{l}-0.0942 \\
0.4857\end{array}$ & 1.00000 \\
\hline
\end{tabular}

Source: Authors' tabulation

Notes: Number of observations is 57. Significance levels are reported under each Pearson correlation coefficient. ${ }^{*} \mathrm{p}<0.05$. English-speaking country is a dummy that takes 1 if a student intends to move to one of the English-speaking countries (Australia, Canada, Ireland, New Zealand, UK, USA), 0 otherwise. German-speaking country is a dummy that takes 1 if a student intends to move to one of the German-speaking countries (Austria, Belgium, Luxembourg, Switzerland), 0 otherwise. 
Table A6: Probit estimates for intention to migrate

\begin{tabular}{|c|c|c|c|c|c|c|c|}
\hline Variables & (1) & (2) & (3) & (4) & (5) & (6) & (7) \\
\hline \multicolumn{8}{|l|}{ Big Five personality traits } \\
\hline \multirow[t]{2}{*}{ Extraversion } & $0.018 * * *$ & $0.009 *$ & & $0.010 * *$ & & $0.011 * *$ & \\
\hline & $(0.005)$ & $(0.005)$ & & $(0.005)$ & & $(0.005)$ & \\
\hline \multirow[t]{2}{*}{ Agreeableness } & $-0.027 * * *$ & $-0.024 * * *$ & & $-0.027 * * *$ & & $-0.025 * * *$ & \\
\hline & $(0.004)$ & $(0.004)$ & & $(0.005)$ & & $(0.005)$ & \\
\hline \multirow[t]{2}{*}{ Conscientiousness } & $-0.019 * * *$ & $-0.022 * * *$ & & $-0.021 * * *$ & & $-0.022 * * *$ & \\
\hline & $(0.005)$ & $(0.005)$ & & $(0.005)$ & & $(0.005)$ & \\
\hline \multirow[t]{2}{*}{ Emotional stability } & $-0.014 * * *$ & $-0.017 * * *$ & & $-0.014 * * *$ & & $-0.013 * * *$ & \\
\hline & $(0.004)$ & $(0.004)$ & & $(0.005)$ & & $(0.005)$ & \\
\hline \multirow[t]{2}{*}{ Openness } & $0.026^{* * *} *$ & $0.024 * * *$ & & $0.025 * * *$ & & $0.022 * * *$ & \\
\hline & $(0.005)$ & $(0.004)$ & & $(0.004)$ & & $(0.005)$ & \\
\hline \multirow[t]{2}{*}{ Risk aversion } & & $-0.050 * * *$ & $-0.051 * * *$ & $-0.046^{* * *} *$ & $-0.048 * * *$ & $-0.047 * * *$ & $-0.049 * * *$ \\
\hline & & $(0.004)$ & $(0.004)$ & $(0.004)$ & $(0.004)$ & $(0.004)$ & $(0.004)$ \\
\hline \multirow[t]{2}{*}{ Impatience } & & -0.004 & $0.008 *$ & -0.005 & 0.006 & -0.003 & $0.008^{*}$ \\
\hline & & $(0.005)$ & $(0.004)$ & $(0.005)$ & $(0.004)$ & $(0.005)$ & $(0.004)$ \\
\hline \multirow[t]{2}{*}{ Age } & & & & $-0.007 * * *$ & $-0.007 * * *$ & $-0.006^{* * *}$ & $-0.006 * * *$ \\
\hline & & & & $(0.001)$ & $(0.001)$ & $(0.002)$ & $(0.002)$ \\
\hline \multirow[t]{2}{*}{ Female } & & & & $0.031 * * *$ & $0.019 * *$ & $0.022 * *$ & 0.010 \\
\hline & & & & $(0.009)$ & $(0.009)$ & $(0.010)$ & $(0.009)$ \\
\hline \multirow[t]{2}{*}{ Having a stable relation } & & & & $-0.100 * * *$ & $-0.102 * * *$ & $-0.098 * * *$ & $-0.100 * * *$ \\
\hline & & & & $(0.009)$ & $(0.009)$ & $(0.009)$ & $(0.009)$ \\
\hline \multirow[t]{2}{*}{ Immigrant background } & & & & $0.042 * * *$ & $0.040 * * *$ & $0.038 * * *$ & $0.037 * * *$ \\
\hline & & & & $(0.011)$ & $(0.011)$ & $(0.011)$ & $(0.011)$ \\
\hline \multirow[t]{2}{*}{ GPA } & & & & & & $-0.010^{* * *}$ & $-0.010 * * *$ \\
\hline & & & & & & $(0.003)$ & $(0.003)$ \\
\hline \multicolumn{8}{|l|}{ Level of study (base: Bachelor's) } \\
\hline Master's & & & & & & $-0.040 * * *$ & $-0.041 * * *$ \\
\hline & & & & & & $(0.010)$ & $(0.010)$ \\
\hline $\mathrm{PhD}$ & & & & & & $0.127 *$ & $0.147 * *$ \\
\hline & & & & & & $(0.067)$ & $(0.068)$ \\
\hline Study field (base: Economics) & & & & & & & \\
\hline Education & & & & & & $-0.107 * * *$ & $-0.107 * * *$ \\
\hline & & & & & & $(0.019)$ & $(0.019)$ \\
\hline Computer sciences & & & & & & -0.003 & 0.000 \\
\hline & & & & & & $(0.020)$ & $(0.020)$ \\
\hline Engineering sciences & & & & & & $-0.040^{* * *}$ & $-0.037 * * *$ \\
\hline & & & & & & $(0.014)$ & $(0.014)$ \\
\hline Art \& Music & & & & & & 0.009 & 0.034 \\
\hline & & & & & & $(0.028)$ & $(0.029)$ \\
\hline Mathematics & & & & & & $-0.102 * * *$ & $-0.099 * * *$ \\
\hline & & & & & & $(0.025)$ & $(0.025)$ \\
\hline Media \& Communication & & & & & & -0.019 & -0.009 \\
\hline & & & & & & $(0.020)$ & $(0.020)$ \\
\hline Medical sciences & & & & & & 0.017 & 0.022 \\
\hline & & & & & & $(0.025)$ & $(0.025)$ \\
\hline Natural sciences & & & & & & -0.010 & -0.006 \\
\hline & & & & & & $(0.017)$ & $(0.017)$ \\
\hline Psychology & & & & & & -0.036 & -0.033 \\
\hline & & & & & & $(0.025)$ & $(0.025)$ \\
\hline Law & & & & & & $-0.041^{*}$ & -0.033 \\
\hline & & & & & & $(0.022)$ & $(0.023)$ \\
\hline Religion & & & & & & $-0.084 *$ & $-0.089 *$ \\
\hline & & & & & & $(0.050)$ & $(0.047)$ \\
\hline Social sciences \& Humanities & & & & & & $-0.042 * * *$ & $-0.034 * *$ \\
\hline & & & & & & $(0.015)$ & $(0.015)$ \\
\hline Sports & & & & & & $-0.076^{* *}$ & $-0.075^{* *}$ \\
\hline & & & & & & $(0.034)$ & $(0.033)$ \\
\hline Language \& Culture & & & & & & $0.059 * * *$ & $0.073^{* * * *}$ \\
\hline & & & & & & $(0.019)$ & $(0.019)$ \\
\hline Observations & 8,572 & 8,572 & 8,572 & 8,572 & 8,572 & 8,477 & 8,477 \\
\hline Pseudo R-squared & 0.0125 & 0.0284 & 0.0174 & 0.0521 & 0.0408 & 0.0679 & 0.0577 \\
\hline Log pseudolikelihood & -4129.17 & -4062.46 & -4108.80 & -3963.44 & -4010.96 & -3855.99 & -3898.13 \\
\hline
\end{tabular}


Table A7: OLS estimates for cultural distance

\begin{tabular}{|c|c|c|c|c|c|}
\hline Variables & (1) & (2) & (3) & (4) & (5) \\
\hline \multicolumn{6}{|c|}{ Big Five personality traits } \\
\hline Extraversion & $\begin{array}{l}-0.051 * * \\
(0.024)\end{array}$ & $\begin{array}{l}-0.055^{* *} \\
(0.025)\end{array}$ & & $\begin{array}{l}-0.052 * * \\
(0.025)\end{array}$ & $\begin{array}{l}-0.053 * * \\
(0.021)\end{array}$ \\
\hline Agreeableness & $\begin{array}{l}0.011 \\
(0.025)\end{array}$ & $\begin{array}{l}0.012 \\
(0.025)\end{array}$ & & $\begin{array}{l}0.015 \\
(0.025)\end{array}$ & $\begin{array}{l}0.001 \\
(0.022)\end{array}$ \\
\hline Conscientiousness & $\begin{array}{l}-0.047 * * \\
(0.022)\end{array}$ & $\begin{array}{l}-0.041 \\
(0.026)\end{array}$ & & $\begin{array}{l}-0.035 \\
(0.026)\end{array}$ & $\begin{array}{l}-0.007 \\
(0.023)\end{array}$ \\
\hline Emotional stability & $\begin{array}{l}0.002 \\
(0.023)\end{array}$ & $\begin{array}{l}0.002 \\
(0.023)\end{array}$ & & $\begin{array}{l}-0.005 \\
(0.024)\end{array}$ & $\begin{array}{l}0.009 \\
(0.021)\end{array}$ \\
\hline Openness & $\begin{array}{l}0.045^{*} \\
(0.024)\end{array}$ & $\begin{array}{l}0.045^{*} \\
(0.024)\end{array}$ & & $\begin{array}{l}0.046^{*} \\
(0.024)\end{array}$ & $\begin{array}{l}0.044 * * \\
(0.020)\end{array}$ \\
\hline Risk aversion & & $\begin{array}{l}-0.021 \\
(0.023)\end{array}$ & $\begin{array}{l}-0.014 \\
(0.022)\end{array}$ & $\begin{array}{l}-0.018 \\
(0.023)\end{array}$ & $\begin{array}{l}-0.013 \\
(0.020)\end{array}$ \\
\hline Impatience & & $\begin{array}{l}0.014 \\
(0.027)\end{array}$ & $\begin{array}{l}0.033 \\
(0.022)\end{array}$ & $\begin{array}{l}0.011 \\
(0.026)\end{array}$ & $\begin{array}{l}0.003 \\
(0.023)\end{array}$ \\
\hline Age & & & & $\begin{array}{l}0.023 * * * \\
(0.008)\end{array}$ & $\begin{array}{l}0.009 \\
(0.007)\end{array}$ \\
\hline Female & & & & $\begin{array}{l}-0.026 \\
(0.052)\end{array}$ & $\begin{array}{l}-0.032 \\
(0.045)\end{array}$ \\
\hline GPA & & & & $\begin{array}{l}0.015 \\
(0.016)\end{array}$ & $\begin{array}{l}0.015 \\
(0.014)\end{array}$ \\
\hline Geographic distance & & & & & $\begin{array}{l}0.012 * * * \\
(0.003)\end{array}$ \\
\hline Diff GDP level & & & & & $\begin{array}{l}-0.569 * * * \\
(0.028)\end{array}$ \\
\hline Free mobility & & & & & $\begin{array}{l}0.840 * * * \\
(0.048)\end{array}$ \\
\hline Constant & $\begin{array}{l}0.982 * * * \\
(0.022)\end{array}$ & $\begin{array}{l}0.982 * * * \\
(0.022)\end{array}$ & $\begin{array}{l}0.982 * * * \\
(0.022)\end{array}$ & $\begin{array}{l}0.433 * * \\
(0.194)\end{array}$ & $\begin{array}{l}0.303^{*} \\
(0.162)\end{array}$ \\
\hline Observations & 1,638 & 1,638 & 1,638 & 1,638 & 1,638 \\
\hline & 0.006 & 0.007 & 0.001 & 0.013 & 0.277 \\
\hline $\begin{array}{l}\text { Source: Authors' tabu } \\
\text { Notes: Dependent vari } \\
\text { most preferred destir } \\
\text { constructed through fo } \\
\text { and Singh (1988). Coe } \\
\text { errors are in parenthes }\end{array}$ & $\begin{array}{l}\text { tural dist } \\
\text { ntry a st } \\
\text { de nation } \\
\text { om OLS }\end{array}$ & $\begin{array}{l}e \text { measure } \\
\text { ent is wil } \\
\text { ulture din } \\
\text { mations a }\end{array}$ & $\begin{array}{l}y \text { the dif } \\
\text { to mis } \\
\text { sions bas } \\
\text { resented }\end{array}$ & $\begin{array}{l}\text { nce of Ger } \\
\mathrm{e} \text { in a co } \\
\text { on the for } \\
\text { columns. R }\end{array}$ & $\begin{array}{l}\text { ny from the } \\
\text { osite index } \\
\text { la of Kogut } \\
\text { ust standard }\end{array}$ \\
\hline
\end{tabular}


Table A8: Multinomial logit estimates for language distance

\begin{tabular}{|c|c|c|c|c|c|c|}
\hline \multirow[b]{2}{*}{ Variables } & \multicolumn{2}{|c|}{ German-speaking country } & \multicolumn{2}{|c|}{ English-speaking country } & \multicolumn{2}{|c|}{ Other countries } \\
\hline & (1) & (2) & (3) & (4) & & (6) \\
\hline \multicolumn{7}{|c|}{ Big Five personality traits } \\
\hline \multirow[t]{2}{*}{ Extraversion } & $0.014 *$ & 0.003 & 0.013 & $0.021 * *$ & $-0.027 * *$ & $-0.024 * *$ \\
\hline & $(0.008)$ & $(0.005)$ & $(0.013)$ & $(0.011)$ & $(0.013)$ & $(0.011)$ \\
\hline \multirow[t]{2}{*}{ Agreeableness } & $-0.019^{* *}$ & $-0.011 * *$ & -0.010 & -0.009 & $0.029 * *$ & $0.020^{*}$ \\
\hline & $(0.008)$ & $(0.005)$ & $(0.013)$ & $(0.010)$ & $(0.013)$ & $(0.011)$ \\
\hline \multirow[t]{2}{*}{ Conscientiousness } & $0.021 * * *$ & $0.011 *$ & $0.024 *$ & -0.005 & $-0.045^{* * *}$ & -0.006 \\
\hline & $(0.008)$ & $(0.006)$ & $(0.013)$ & $(0.012)$ & $(0.013)$ & $(0.013)$ \\
\hline \multirow[t]{2}{*}{ Emotional stability } & -0.004 & 0.001 & 0.008 & 0.004 & -0.004 & -0.005 \\
\hline & $(0.008)$ & $(0.005)$ & $(0.013)$ & $(0.010)$ & $(0.013)$ & $(0.011)$ \\
\hline \multirow[t]{2}{*}{ Openness } & -0.000 & -0.006 & -0.014 & 0.001 & 0.014 & 0.004 \\
\hline & $(0.008)$ & $(0.005)$ & $(0.013)$ & $(0.010)$ & $(0.013)$ & $(0.011)$ \\
\hline \multirow[t]{2}{*}{ Risk aversion } & & 0.001 & & 0.004 & & -0.005 \\
\hline & & $(0.005)$ & & $(0.009)$ & & $(0.010)$ \\
\hline \multirow[t]{2}{*}{ Impatience } & & -0.003 & & -0.007 & & 0.009 \\
\hline & & $(0.006)$ & & $(0.011)$ & & $(0.012)$ \\
\hline \multirow[t]{2}{*}{ Age } & & -0.001 & & $-0.006^{*}$ & & $0.007 *$ \\
\hline & & $(0.002)$ & & $(0.003)$ & & $(0.004)$ \\
\hline \multirow[t]{2}{*}{ Female } & & -0.004 & & 0.019 & & -0.015 \\
\hline & & $(0.010)$ & & $(0.022)$ & & $(0.024)$ \\
\hline \multirow[t]{2}{*}{ GPA } & & -0.002 & & -0.010 & & 0.012 \\
\hline & & $(0.003)$ & & $(0.006)$ & & $(0.007)$ \\
\hline \multirow[t]{2}{*}{ Geographic distance } & & $-0.158 * * *$ & & $0.117 * * *$ & & $0.041 * * *$ \\
\hline & & $(0.015)$ & & $(0.008)$ & & $(0.008)$ \\
\hline \multirow[t]{2}{*}{ Diff GDP level } & & $0.200 * * *$ & & $0.225 * * *$ & & $-0.425^{* * *}$ \\
\hline & & $(0.008)$ & & $(0.011)$ & & $(0.012)$ \\
\hline Observations & 1,638 & 1,638 & 1,638 & 1,638 & 1,638 & 1,638 \\
\hline Pseudo R-squared & 0.0088 & 0.4353 & 0.0088 & 0.4353 & 0.0088 & 0.4353 \\
\hline Log pseudolikelihood & -1546.07 & -880.79 & -1546.07 & -880.79 & -1546.07 & -880.79 \\
\hline \multicolumn{7}{|c|}{ Source: Authors' tabulation } \\
\hline \multicolumn{7}{|c|}{$\begin{array}{l}\text { Notes: Dependent variable is language distance, a categorical variable taking } 0 \text { if a student reports a German-speaking } \\
\text { country as a preferred destination, } 1 \text { if an English-speaking country, and } 2 \text { otherwise. Marginal effects from multinomial } \\
\text { logit estimation are presented in columns. Free mobility dummy is excluded in specifications with controls to properly } \\
\text { estimate standard errors since all German-speaking countries have a free mobility agreement with Germany and none of } \\
\text { English-speaking countries have such an agreement. Robust standard errors are in parentheses. } * * * p<0.01, * * p<0.05, * \\
\mathrm{p}<0.1 \text {. }\end{array}$} \\
\hline
\end{tabular}


Table A9: Descriptive statistics of unstandardized scores of Big 5 personality traits

\begin{tabular}{lccccc}
\hline Big 5 personality traits & N & Mean & Std. Dev. & Min & Max \\
\hline Full sample & & & & & \\
$\quad$ Extraversion & 8,572 & 32.677 & 6.545 & 15 & 50 \\
Agreeableness & 8,572 & 40.109 & 5.099 & 15 & 50 \\
Conscientiousness & 8,572 & 34.720 & 5.580 & 16 & 50 \\
Emotional stability & 8,572 & 31.655 & 6.599 & 15 & 50 \\
Openness & 8,572 & 37.660 & 4.817 & 19 & 50 \\
Sample of students intending to migrate to countries for which Hofstede index is available & \\
Extraversion & 1,638 & 33.075 & 6.580 & 15 & 50 \\
Agreeableness & 1,638 & 39.549 & 5.297 & 18 & 50 \\
Conscientiousness & 1,638 & 34.123 & 5.897 & 17 & 50 \\
Emotional stability & 1,638 & 31.192 & 6.825 & 15 & 50 \\
Openness & 1,638 & 38.150 & 4.870 & 21 & 50 \\
\hline
\end{tabular}

Source: Authors' tabulation 